\title{
A new species, males and immature stages of Ancystropus, with reference to apomorphic characters and their mode of development (Acarina: Spinturnicidae)
}

\author{
Kimito UahIKawa* \\ Department of Parasitology, Shinshu University School of Medicine, Matsumoto 390, Japan
}

(Received: September 8, 1989)

Key words: Ancystropus, a new species, males and immature stages of known species, evolutoin.

\begin{abstract}
Ancystropus notopteris sp. $\mathrm{n}$. is described on the adult and immature stages. The males of all known species of Ancystropus except A. leleupi and the immature stages of $A$. kanheri, A. eonycteris, $A$. zeleborii and $A$. taprobanius are described or redescribed. Apomorphic characters of Ancystropus are evaluated, and are thought to have come out through sympatric speciations of mites on a few hosts independent of host speciations.
\end{abstract}

Ancystropus Kolenati, 1856, and Meristaspis Kolenati, 1857, in the Spinturnicidae Oudemans, 1902, are associated exclusively with Megachiroptera, or frugivorous bats. Females of these and other spinturnicid genera give birth directly to the protonymph that gives rise to the deutonymph and then to the adult, without leaving the host bat. Although it is important to define the morphology of all stages of these mites for systematic, ecological and faunal studies, earlier work particularly on Ancystropus has been based largely on females.

Morphological differences between males or immature stages of Ancystropus are not as marked as those between females, and several species of this genus sometimes share a given host bat with at least 2 species of the allied Meristaspis. This slowed the progress of classification of the males and immature stages, and caused some misidentifications. Thus Turk (1950) mistook the male of Meristaspis lateralis (Kolenati, 1856) for that of Ancystropus taprobanius (Turk, 1950) in his

* 内川公人：信州大学医学部寄生虫学教室（干390 松 本市地 3-1-1) original description of the latter (Rudnick, 1960). Prasad (1969) partially described the male of $A$. taprobanius under a different specific name (Domrow, 1972). Rudnick (1960) examined a single male of Ancystropus aethiopicus Hirst, 1923, in rather poor condition, and gave few morphological details. Dusbábek and Bergmans (1980) recorded 6 males of $A$. aethiopicus without mentioning morphology. Ancystropus kanheri Hiregaudar and Bal, 1955, Ancystropus leleupi Benoit, 1959, and Ancystropus eonycteris Delfinado and Baker, 1963, were previously known only from females. Only $A n$ cystropus zeleborii Kolenati, 1856, was known from both sexes, its male having been well described by Rudnick (1960). No morphological data for differentiating immature stages were available.

I have examined numerous specimens of Ancystropus from various sources, and found all stages of a new species. The males of all other known species except $A$. leleupi have been correlated with their respective partner females. The immature stages of $A$. kanheri, A. eonycteris, $A$. zeleborii and $A$. taprobanius can now be defined morphologically. This 
material is figured and described below with supplemental host records. Measurements are in $\mu \mathrm{m}$, and setal nomenclature as in Domrow (1972).

\section{Materials ANd Methods}

Skin and alcoholic specimens of frugivorous bats in the following museums were examined for spinturnicid mites in 1982: B. P. Bishop Museum (BBM), Honolulu; Field Museum of Natural History (FMNH), Chicago; American Museum of Natural History (AMNH), New York; US National Museum of Natural History, Smithsonian Institution (USNM), Washington, D.G.;
British Museum (Natural History) (BMNH), London; Natur-Museum Senckenberg (SMF), Frankfurt; and Rijksmuseum van Natuurlijke Historie (RMNH), Leiden. Mites were taken off with a fine needle and forceps from skin specimens of bats either with the naked eye or under the dissecting microscope, and were washed out in alcohol from alcoholic specimens of bats. The collection data for each host were taken directly from the museum label.

Mites were also taken as above from alcoholic specimens of bats collected by Dr. M. Harada in Thailand in 1979 and 1982, and Dr. T. Kobayashi, Dr. M. Harada and Dr. K. Maeda in Borneo in 1976 and 1979.

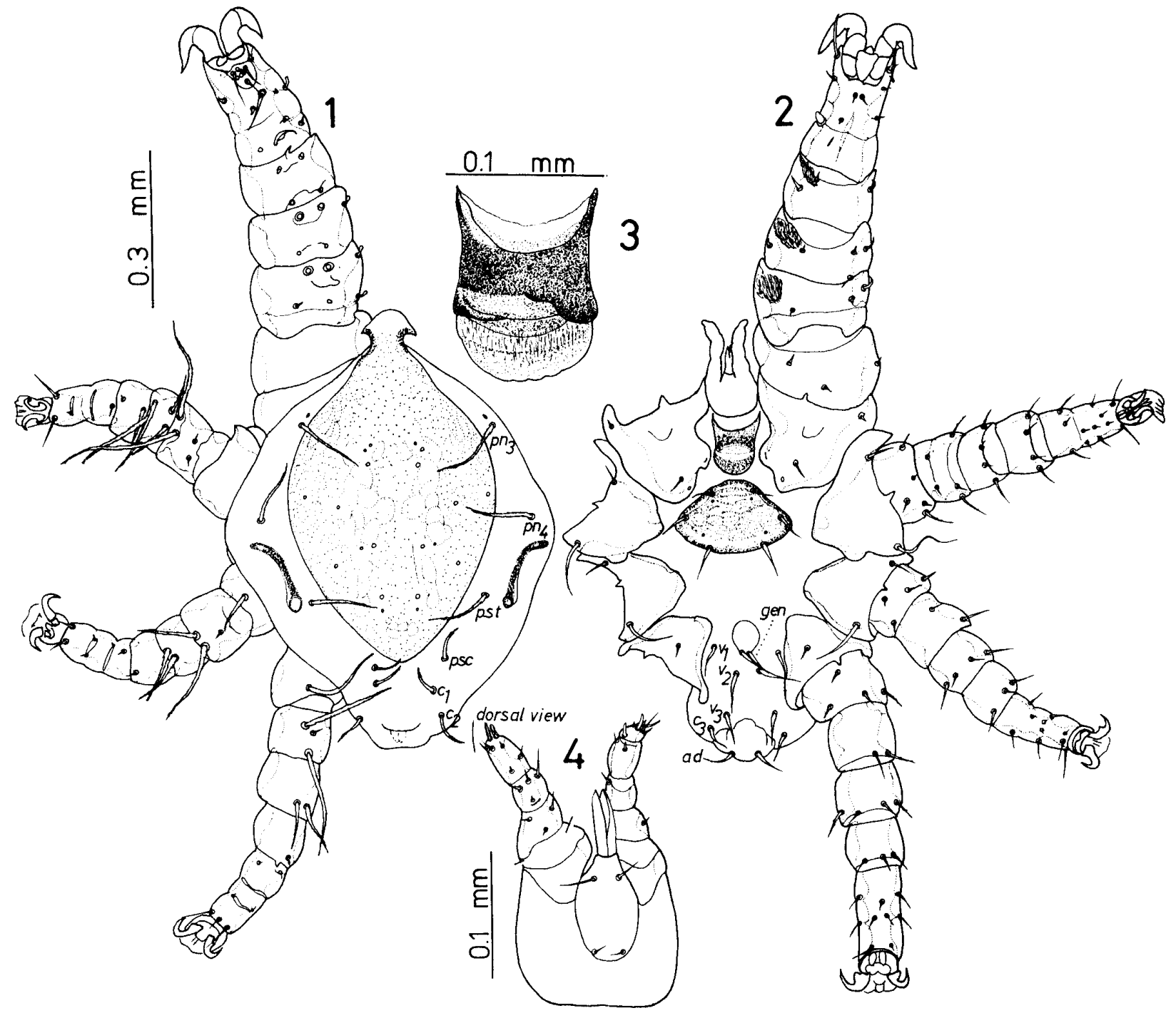

Figs. 1-4 Ancystropus notopteris sp. n., female.

1: dorsal view; pn 3-4, proteronotal setae 3-4; pst, poststigmal seta; psc, postscutal seta: $c 1-2$, caudal setae 1-2. 2: ventral view; gen, genital seta; $v 1-3$, ventral setae $1-3 ; c 3$, caudal seta $3 ; a d$, adanal seta. 3: tritosternum. 4: gnathosoma, ventral view. 
Dr. H. Suzuki provided mites taken from Thai frugivorous bats in 1978.

\section{Ancystropus notopteris sp. $\mathrm{n}$.}

(Figs. 1-10)

Female (Figs. 1-4). Two unfed and 1 partially fed specimens available.

Idiosoma widest at anterior level of peritremes and narrowed at anterior and posterior ends. Dorsal shield oval, with anterior projection, and bearing 10 pairs of pores and ornamentation (Fig. 1). Proteronotal seta 1 missing; seta 2 reduced to its vestigial base discernible close to seta 3 ; setae 3 and 4 and poststigmal seta well-developed and long. Postscutal seta long; 3 pairs of caudal setae including 1 pair situated ventrally on unfed specimens (Fig. 2) long. Tritosternum vase-like, with concave anterior margin (Figs. 2,3 ). Sternal shield shell-shaped, widest at a level slightly behind sternal seta 2 , striated faintly and bearing 3 pairs of strong sternal setae and 2 pairs of pores. Metasternal seta missing; genital seta and 3 pairs of ventral setae well-developed; adanal setae also strong (Fig. 2).

Legs as in Figs. 1 and 2; leg I thick and long, bearing a pair of strong claws and lacking pulvillus, not armed with hook or spur; a finely striated patch ventrally on anterodistal corner of femur, genu and tibia I (Fig. 2) ; basal anteroventral seta on tarsus I knob-like. Leg chaetotaxy after Evans

Table 1 Leg chaetotaxy for female of $A$. notopteris sp. n.

\begin{tabular}{rrcccccc}
\hline & Coxa & Trochanter & Femur & Genu & Tibia & Tarsus \\
\hline Leg & I & 2 & 5 & $2-4 / 3-2$ & $2-2 / 1,2 / 1-1$ & $2-2 / 1,2 / 1-1$ & 31 \\
II & 2 & 5 & $1-4 / 3-1$ & $1-2 / 1,2 / 1-1$ & $1-1 / 1,2 / 1-1$ & 16 \\
III & 2 & 5 & $1-3 / 2-0$ & $1-1 / 1,1 / 1-1$ & $1-0 / 1,1 / 0-1$ & 16 \\
IV & 1 & 5 & $1-3 / 1-0$ & $1-1 / 1,1 / 1-1$ & $1-0 / 1,1 / 0-1$ & 16 \\
\hline
\end{tabular}

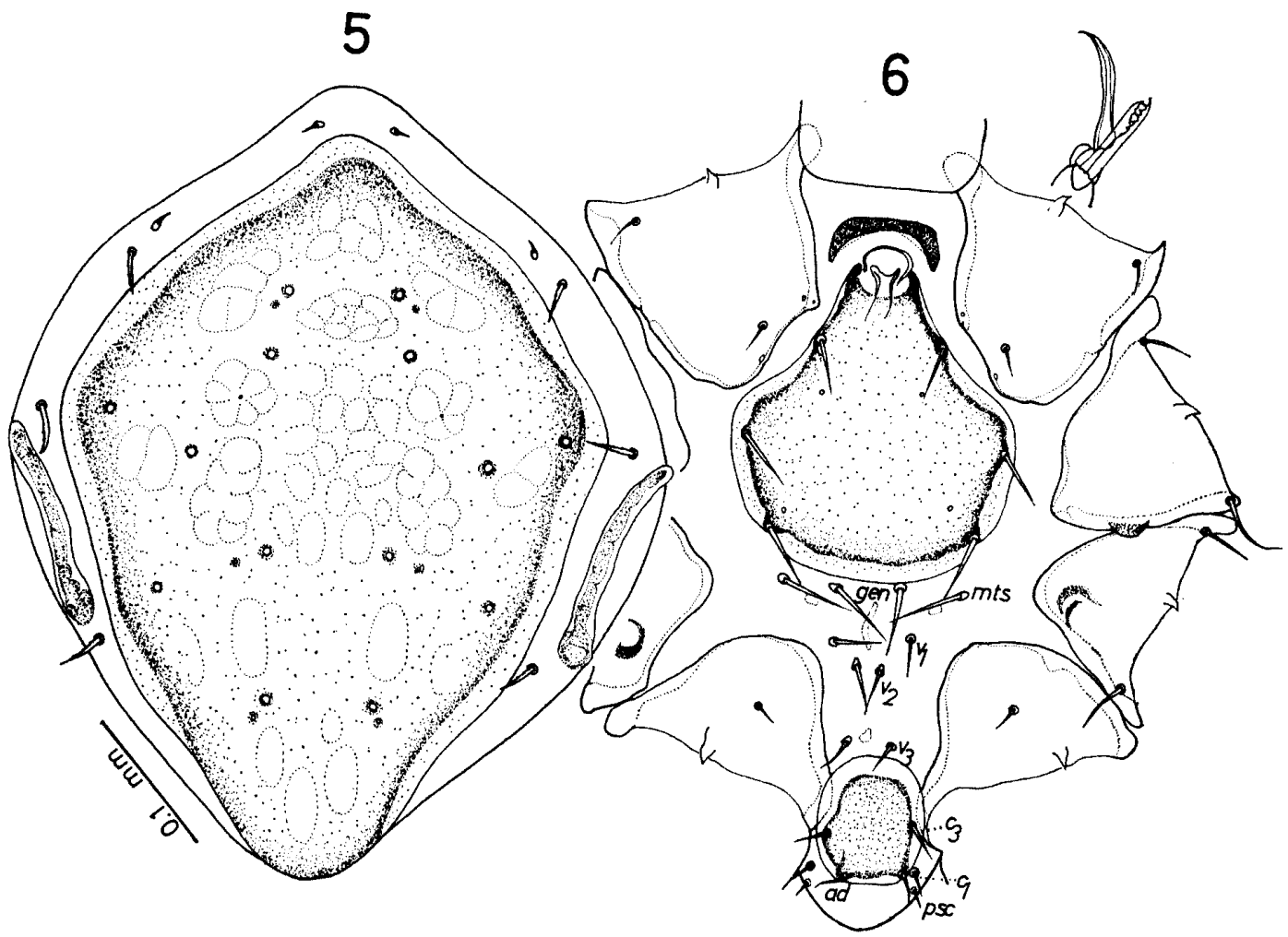

Figs. 5, 6 Ancystropus notopteris sp. n., male.

5: idiosomal dorsum. 6: idiosomal venter and tip of chelicera; $m t s$, metasternal seta; other symbols as in Fig. 2. 
(1968) as in Table 1.

Gnathosoma as in Figs. 2 and 4.

Measurements for holotype and 1 paratype (both unfed) : Idiosoma 840-810 long, 600590 wide; dorsal shield 670-690 long, 420400 wide; proteronotal setae 3,4 and poststigmal seta 140-123, 120-102 and 120-100 long, respectively; postscutal seta 58-70 long; caudal seta 53-60 long; tritosternum 85-90 long (medially), 95-95 wide; sternal shield 147-155 long, 225-225 wide; sternal seta 3 75-70 long; genital seta 55-60 long; longest ventral seta 80-85 long; adanal seta 80-75 long; leg I 900-880 long, 230-220 wide (maximum); leg IV 690-690 long.

Male (Figs. 5, 6). Dorsal shield completely covering idiosoma caudally. Proteronotal setae 1 and 2 distinctly shorter than succeeding propodonotal and poststigmal setae (Fig. 5) ; a pair of postscutal setae and 2 pairs of caudal setae present (Fig. 6). Tritosternum broad and crescentic, its pos- terior margin surrounding genital orifice. Sternogenital shield flask-shaped with broadly rounded posterior margin barely reaching to bases of genital setae, bearing 3 pairs of strong sternal setae and 2 pairs of pores. Metasternal and genital setae situated at almost the same level and stronger than 3 pairs of ventral setae (Fig. 6).

Leg I not as strong as in female and almost the same in shape as other legs; leg chaetotaxy as in female.

Spermadactyl sinuate, long, and emerging behind tip of movable digit (Fig. 6) ; other structures of gnathosoma as in female.

Measurements as in Table 2.

Deutonymph. Female- and male-deutonymphs clearly separable from each other morphologically.

Female-deutonymph (Figs. 7, 8). Idiosoma constricted at basal level of postscutal setae (Fig. 7). Proteronotal setae 1 and 2 (2 lacking unilaterally, Fig. 7) shorter than

Table 2 Measurements (in $\mu \mathrm{m}$ ) for adult males of the genus Ancystropus.

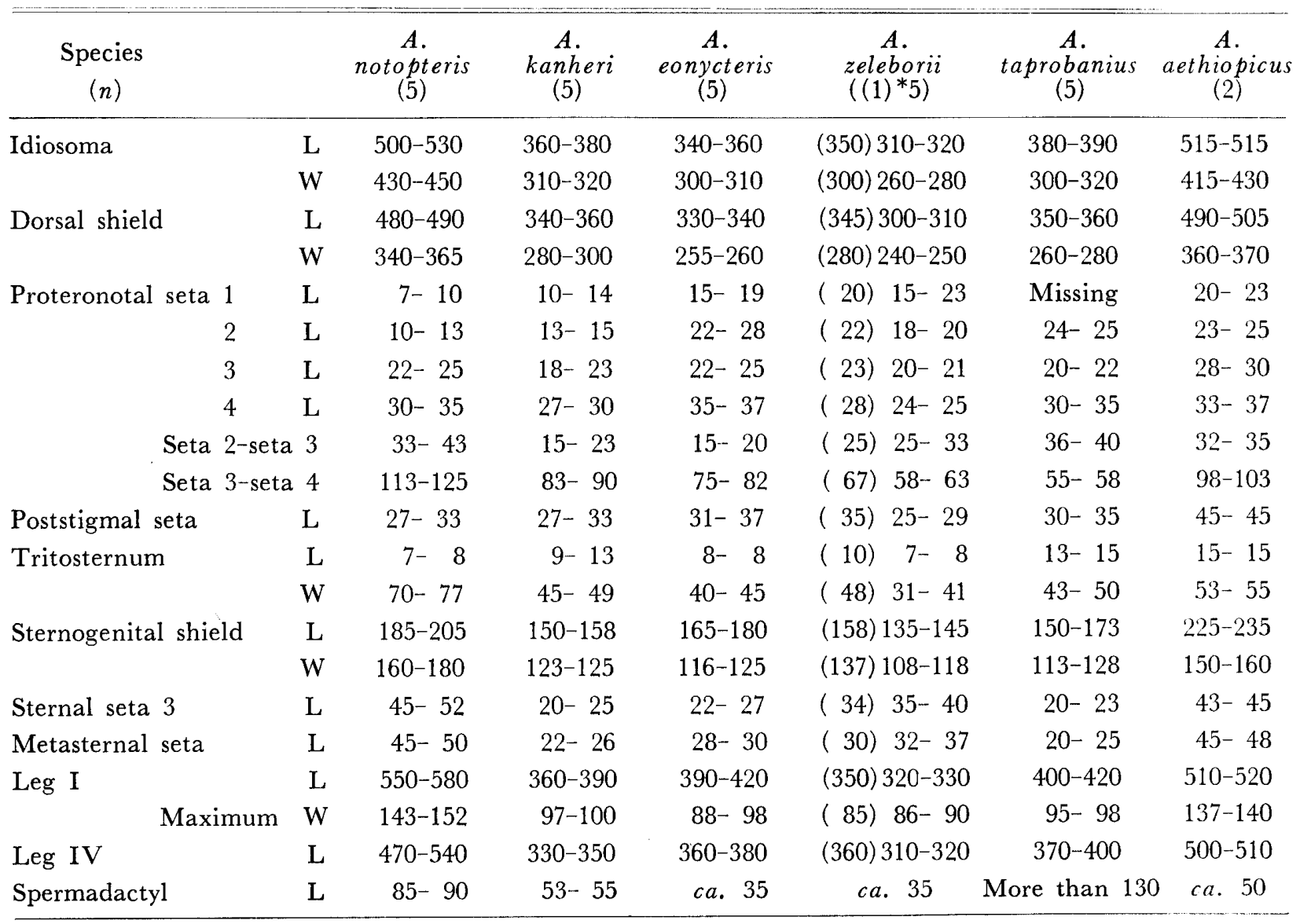

L: length, W: width, seta 2(3)-seta 3(4): distance between 2 setae.

* A single specimen taken from Rousettus aegyptiacus. 


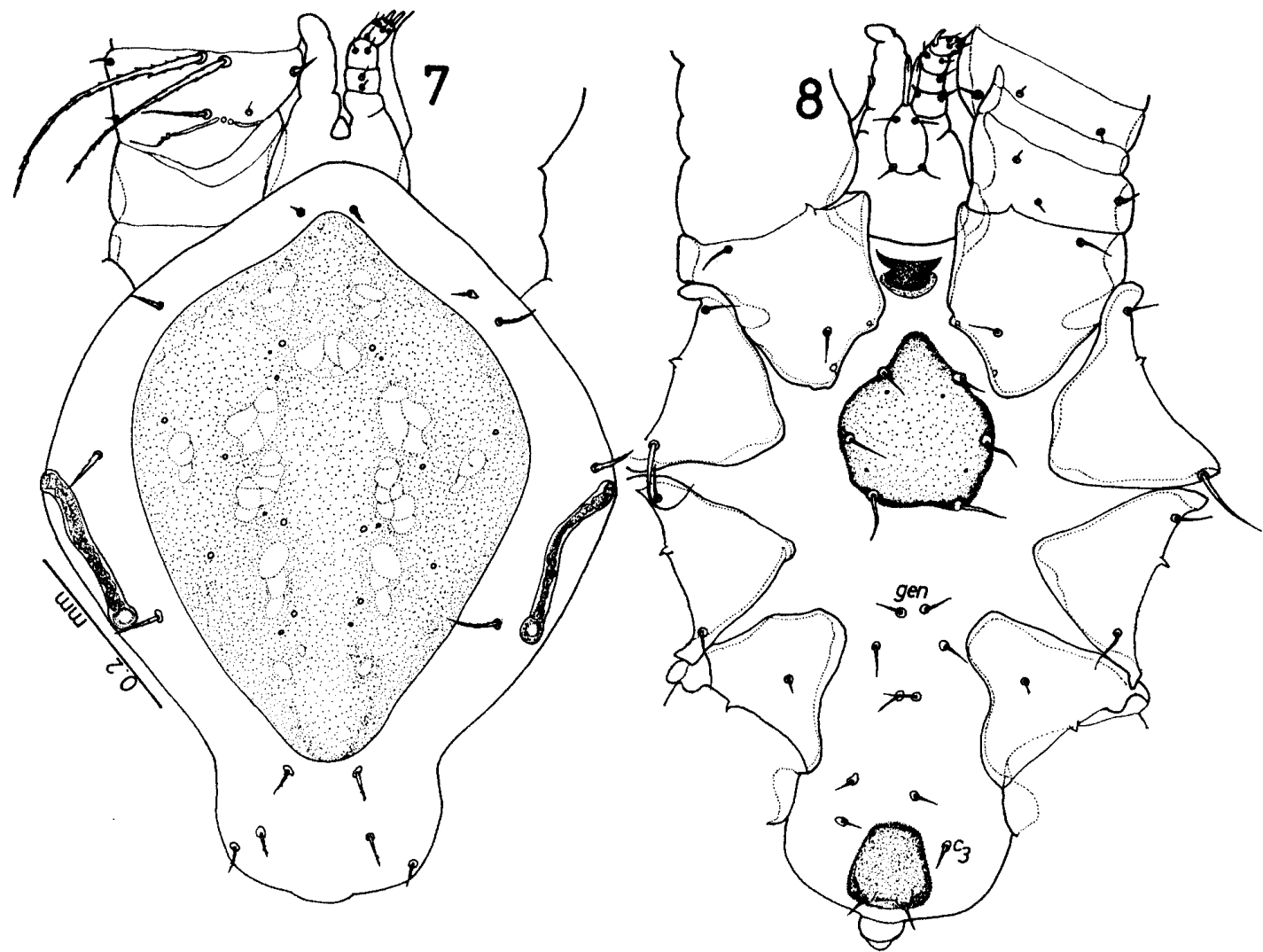

Figs. 7, 8 Ancystropus notopteris, sp. n., female-deutonymph. 7: dorsal view. 8: ventral view.

succeeding setae; setae 2 and 3 closer to each other than to other setae. Tritosternum invaginated laterally, with concave anterior and rounded posterior margins (Fig. 8). Sternal shield rounded pentagonal, and bearing 3 pairs of strong sternal setae. Opisthosomal setation on dorsum and venter as in unfed female although shorter.

Leg I much longer and thicker than other legs; leg chaetotaxy as in adult.

Measurements as in Table 3.

Male-deutonymph. Small, with normal leg I. Tritosternum square with concave lateral margins. Sternal shield with slightly convex posterior margin. Idiosomal and leg setations as in male. Metasternal and genital setae rather strong and situated on almost the same level.

Measurements as in Table 3.

Protonymph. Female- and male-protonymphs separable.

Female-protonymph (Figs. 9, 10). Propodosoma broadly rounded and hysterosoma narrowed. Dorsal shield entire. Proteronotal setae 2 and 3 relatively far apart (Fig. 9).
One pair each of postscutal and caudal setae dorsally on hysterosoma. Tritosternum roughly trapezoidal. Sternal shield rounded pentagonal and bearing slender sternal setae (Fig. 10). One pair of genital setae, 2 pairs of ventral setae and 1 pair of caudal setae present ventrally (Fig. 10).

Leg I thicker and longer than other legs; leg chaetotaxy as in Table 4.

Measurements as in Table 5.

Male-protonymph. Small, with rather slender leg I. Proteronotal setae 2 and 3 close to each other. Sternal shield with distinctly convex posterior margin. Other structures and chaetotaxy as in female-protonymph.

Measurements as in Table 5.

Materials examined. Holotype female, allotype male, 1 paratype female, 4 paratype males, 1 (partially fed, with legs I snapped off), $1 \hat{\delta}$ (damaged), 2 deutonymphs $(=\mathrm{DN})$ and 2 protonymphs $(=\mathrm{PN})$ ex Notopteris macdonaldi, Suva, Fiji Is., May 22, 1950 (FMNH 31252-31344); 1 PN ex N. macdonaldi, Colombo Cave, Suva, Fiji 


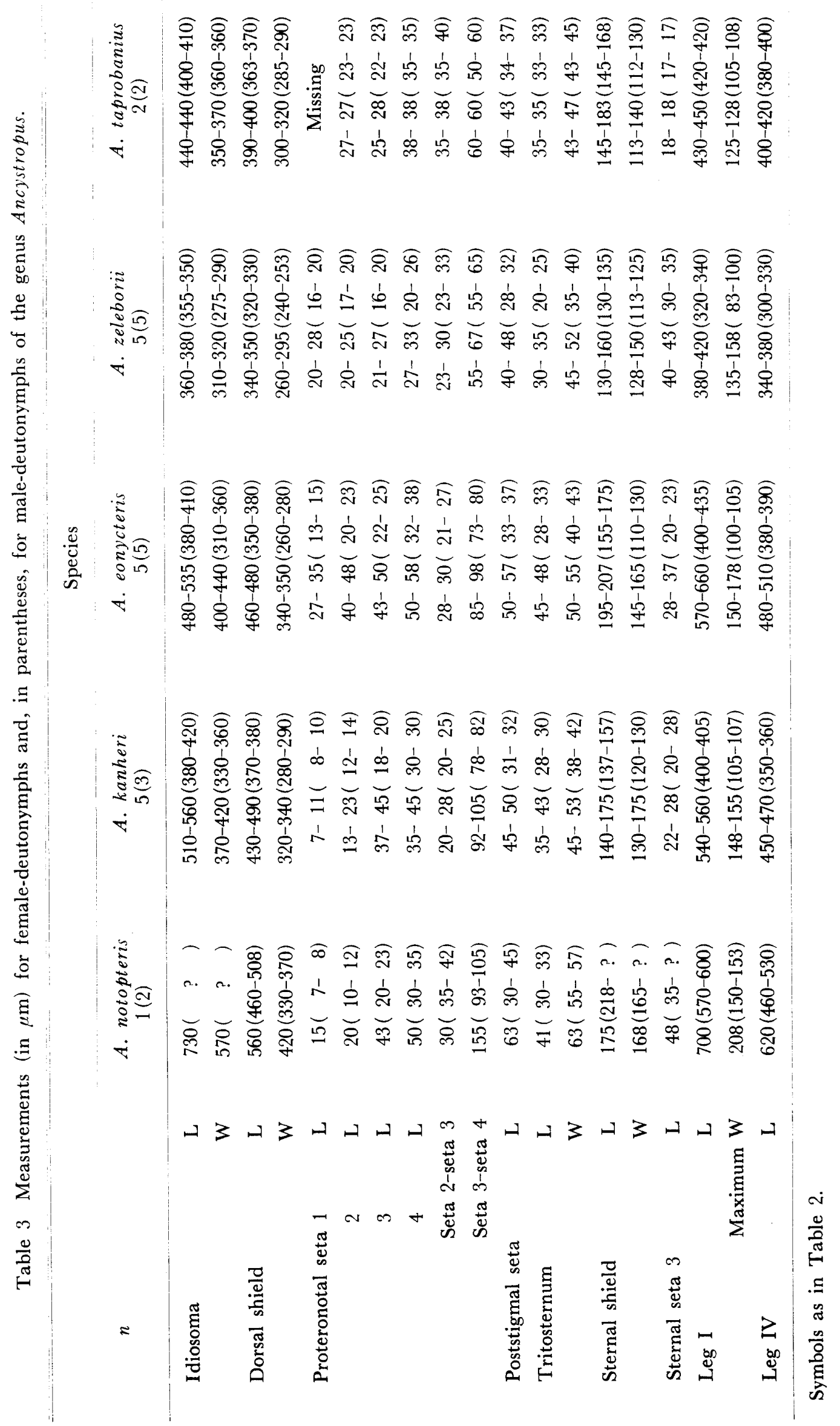


Table 4 Leg chaetotaxy of protonymph (A. notopteris).

\begin{tabular}{|c|c|c|c|c|c|c|}
\hline & Coxa & Trochanter & Femur & Genu & Tibia & Tarsus \\
\hline Leg I & 2 & 4 & $1-4 / 2-1$ & $1-2 / 1,2 / 1-1$ & $1-2 / 1,2 / 1-1$ & 25 \\
\hline II & 2 & 4 & $1-4 / 2-1$ & $1-2 / 0,2 / 0-1$ & $1-1 / 1,2 / 1-1$ & 15 \\
\hline III & 2 & 4 & $1-3 / 1-0$ & $1-1 / 0,1 / 0-1$ & $1-0 / 1,1 / 0-1$ & 15 \\
\hline IV & 1 & 4 & $1-3 / 0-0$ & $1-1 / 0,1 / 0-1$ & $1-0 / 1,1 / 0-1$ & 15 \\
\hline
\end{tabular}

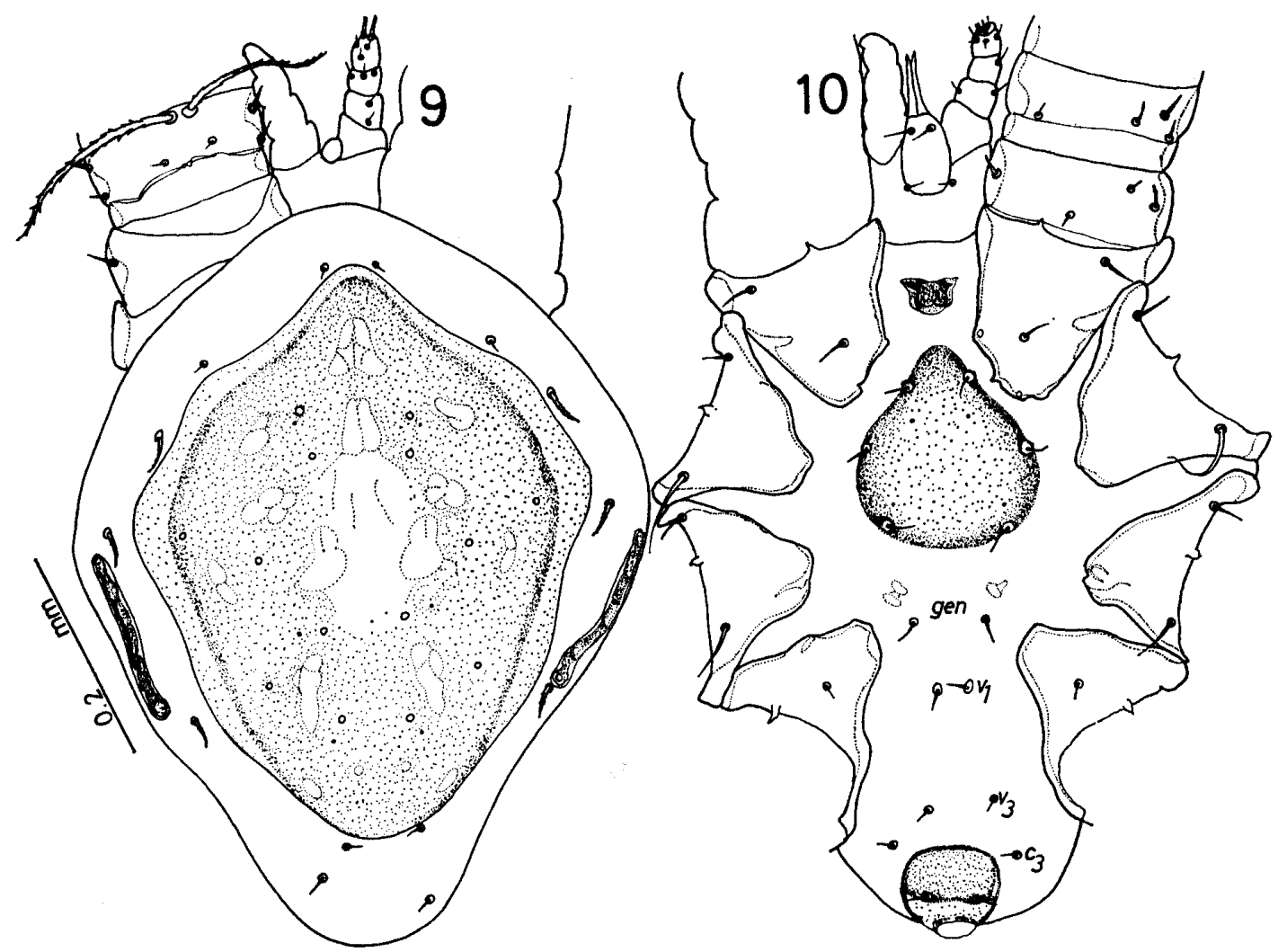

Figs. 9, 10 Ancystropus notopteris, sp. n., female-protonymph. 9: dorsal view. 10: ventral view.

Is., May 22, 1929 (USNM 260070-260079); 16 , 1DN ex Notopteris sp., New Hebrides, date uncertain (SMF 21398-21404); 1 o ex Notopteris neocaledonica, data uncertain (BMNH, no accession No.).

These specimens are deposited in the museums where they were taken, leaving 2 paratype males, 1 damaged male and female, 1 deutonymph and 1 protonymph from the FMNH bats in my collection.

Remarks. Ancystropus notopteris sp. n. is easily separable from all known congeners in all known stages.

The reduced proteronotal seta 2, long proteronotal setae 3 and 4 and poststigmal seta, long postscutal seta, vase-like tritosternum, shell-shaped sternal shield, missing metasternal seta, unarmed (hookless) leg I and femur IV bearing 1 ventral seta are specific characters for the female of the new species. Of these characters, the reduced proteronotal seta 2 and setation of femur IV are also found in $A$. kanheri and $A$. leleupi, and only the setation of femur IV in $A$. aethiopicus. The long postscutal seta occurs only in $A$. taprobanius and the new species.

Differential characters for the male and immature stages are summarized in the keys to species below.

One partially fed female had both legs I snapped off beyond the femur. Domrow (1972) found this type of damage in fed 
females of $A$. kanheri and thought it suggestive that the mite was prehensile on the host bat. Thus the female of $A$. notopteris may have the same attaching habit as in $A$. kanheri.

\section{Ancystropus kanheri Hiregaudar and Bal, 1955}

(Figs. 11 and 17)

Male (Fig. 11). Proteronotal seta 3 slightly longer than seta 2. Postscutal seta thick and more than 15 long. Tritosternum thick, trapezoidal and with distinctly concave posterior margin (Fig. 11). Sternogenital shield broadly rounded posteriorly, not reaching to basal level of genital setae, and bearing 3 pairs of rather slender sternal setae. Metasternal and genital setae almost on the same level, and slightly longer than 3 pairs of ventral setae; 2 pairs of caudal setae on venter (Fig. 11); adanal setae smaller than caudal setae.

Leg chaetotaxy as in A. notopteris.

Spermadactyl weakly sinuate, short, and
Jpn. J. Sanit. Zool.

emerging only slightly behind tips of chelae (Fig. 11).

Measurements as in Table 2.

Female-deutonymph (Fig. 17). Large. Idiosoma and dorsal shield oval. Proteronotal setae 3 and 4 much longer than seta 2 . Postscutal seta (ca. 13 long) smaller than 3 pairs of caudal setae (more than $20 \mathrm{long}$ ). Tritosternum biconcave, trapezoidal and thick. Sternal shield broadly rounded posteriorly, not reaching to basal level of metasternal setae, and bearing 3 pairs of slender setae. Metasternal and genital setae subequal to sternal setae; 3 pairs of ventral setae shorter than genital setae and caudal setae.

Leg I cylindrical, thick and long; no prominent posterodistal projection on tarsus I; leg chaetotaxy as in adult.

Measurements as in Table 3.

Male-deutonymph. Smaller than femaledeutonymph. Leg I slender and shorter than in female-deutonymph. Two pairs of caudal setae present. Sternal shield narrowed posteriorly and reaching to basal level of metasternal setae posteriorly. Idiosomal chaeto-

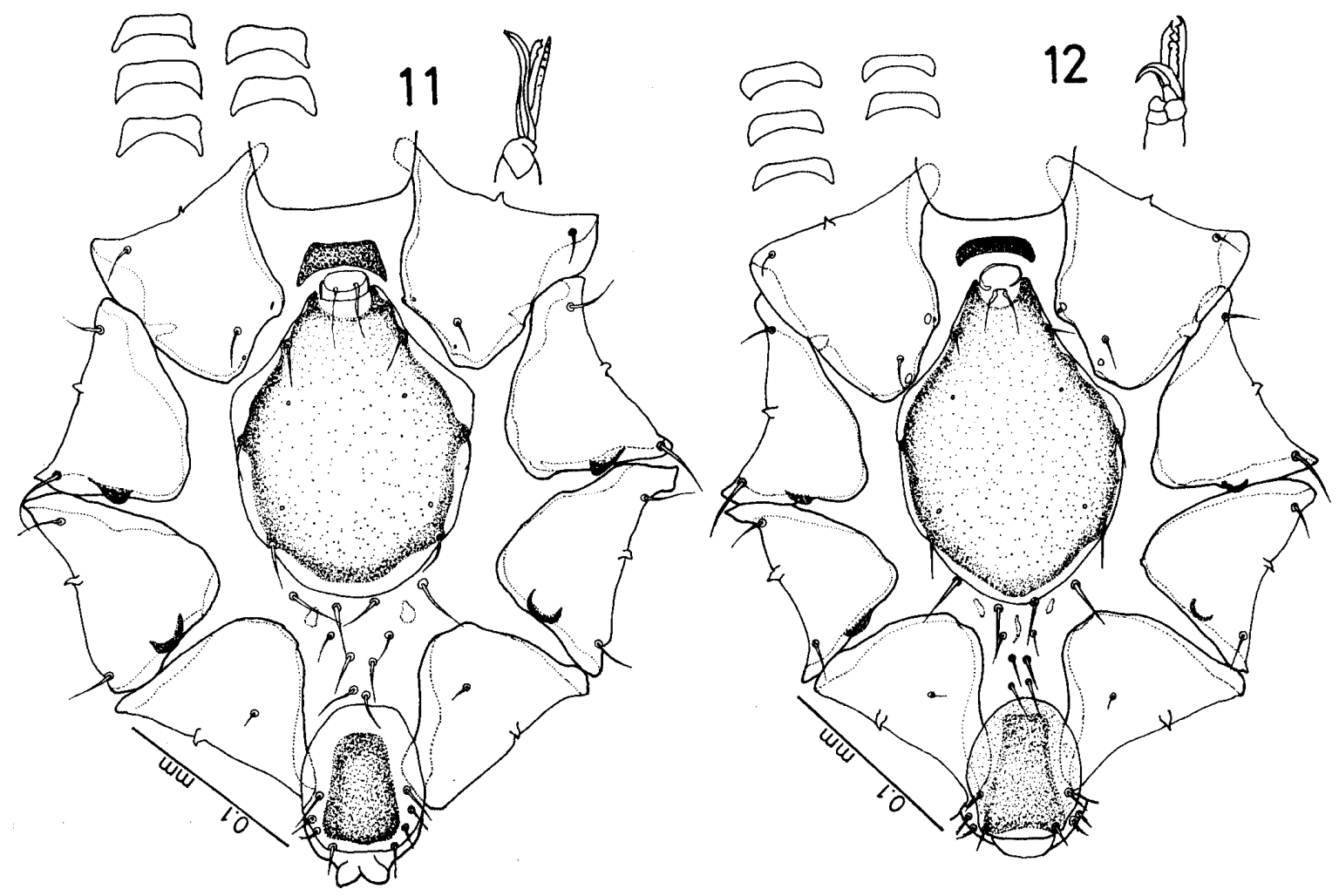

Figs. 11, 12 Male idiosomal venter, tritosternum and tip of chelicera.

11: Ancystropus kanheri Hiregaudar and Bal, 1955. 12: Ancystropus eonycteris Delfinado and Baker, 1963. 
taxy as in male. Other structures and leg chaetotaxy essentially as in female-deutonymph.

Measurements as in Table 3.

Female-protonymph. Idiosoma oval. Dorsal shield entire. Proteronotal seta 2 much shorter than setae 3 and 4 . One pair of postscutal setae, 2 pairs of caudal setae, 1 pair of genital setae and 2 pairs of ventral setae present as in $A$. notopteris. Tritosternum elongate trapezoidal. Sternal shield broadly rounded as in deutonymph.

Leg I thick and long; leg chaetotaxy as in A. notopteris.

Measurements as in Table 5.

Male-protonymph. Small. Leg I slender and shorter than in female-protonymph. Tritosternum distinctly shorter than in female-protonymph. Sternal shield narrowed posteriorly and extending posteriorly beyond bases of sternal seta 3 as in male-deutonymph. Other structures and setation essentially as in female-protonymph.

Measurements as in Table 5.

Materials examined. Ex Rousettus lesche-

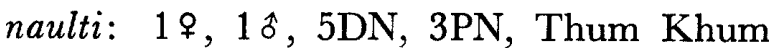
Khoawong Kod, Banmi, Lopburi, Thailand, November 10, 1979; 1ㅇ, 1ㅎ, 1DN, 3PN, Bam Klui, Banmi, Lopburi, Thailand, November $11-12,1979 ; 1 \%, 3 \hat{\delta}, 1 \mathrm{PN}$ Tapkuang Kangkoi, Saraburi, Thailand, November 18, 1979; 1̊, 4to, 4DN, 11PN, Khao Tagra, Muang, Lopburi, Thailand, December 2, 1979. Ex Eonycteris spelaea: 1DN, Khoa Wong Kot, Thamai, Jhanthaburi, November 27, 1979. One $\hat{\alpha}$ without host record and misidentified as Meristaspis mindanaoensis Delfinado and Baker, 1963, in Uchikawa and Kobayashi (1978) (total: 4\%, 10^, 11DN, $18 \mathrm{PN}$ ).

All the above specimens are deposited in my collection.

Remarks. Prasad (1969) presented drawings of the tritosternum, sternogenital shield, sternal, metasternal and genital setae for $A$. zeleborii (p. 674, figs. 36-7). These are actually for $A$. kanheri. Domrow (1972) showed the setal formula of tibia II as 1-2/ $2-1$, not counting an antero-dorsal seta $(a d)$, but the real formula is $1-3 / 2-1$ as in the other species of Ancystropus.

\section{Ancystropus eonycteris \\ Delfinado and Baker, 1963}

(Figs. 12 and 18)

Male (Fig. 12). Proteronotal setae 2 and 3 subequal to each other. Postscutal seta thick and more than 15 long, smaller than 2 pairs of caudal setae. Tritosternum rather thick, with concave posterior margin. Sternogenital shield pear-shaped, with rounded posterior margin, extending posteriorly beyond basal level of metasternal setae and barely reaching to basal level of genital setae, and bearing 3 pairs of rather weak sternal setae and 2 pairs of pores. Metasternal setae situated distinctly anteroexteriad from genital setae; and both setae thicker than sternal setae 3. Three pairs of ventral setae weak; adanal setae thinner than caudal seta. Leg chaetotaxy not as in $A$. notopteris but having 2 antero-ventral setae on femur IV (1-3) $2-0)$ as in partner female.

Spermadactyl curved strongly, and fixed and movable digits accordingly projecting over spermadactyl (Fig. 12).

Measurements as in Table 2.

Female-deutonymph (Fig. 18). Large. Proteronotal setae well-developed; setae 2-4 thick and long. Poststigmal seta also thick and long. Postscutal seta thick and ca. 15 long, smaller than 3 pairs of caudal setae. Tritosternum vase-like, with biconcave, posteriorly rounded margins (Fig. 18). Sternal shield truncate anteriorly and tapering, with concave lateral margins posteriorly, ending between genital setae, and bearing 3 pairs of rather slender sternal setae (Fig. 18). Metasternal and genital setae thicker than sternal and ventral setae.

Leg I thick, long, and cylindrical; leg chaetotaxy as in adult.

Measurements as in Table 3.

Male-deutonymph (Fig. 18). Smaller than female-deutonymph. Idiosomal setae much smaller than those of female. Two pairs of caudal setae present. Tritosternum square (Fig. 18). Sternal shield triangular posteriorly; postero-lateral margins not concave as in female-deutonymph (cf. Fig. 18). Other structures and leg chaetotaxy as in femaledeutonymph.

Measurements as in Table 3. 


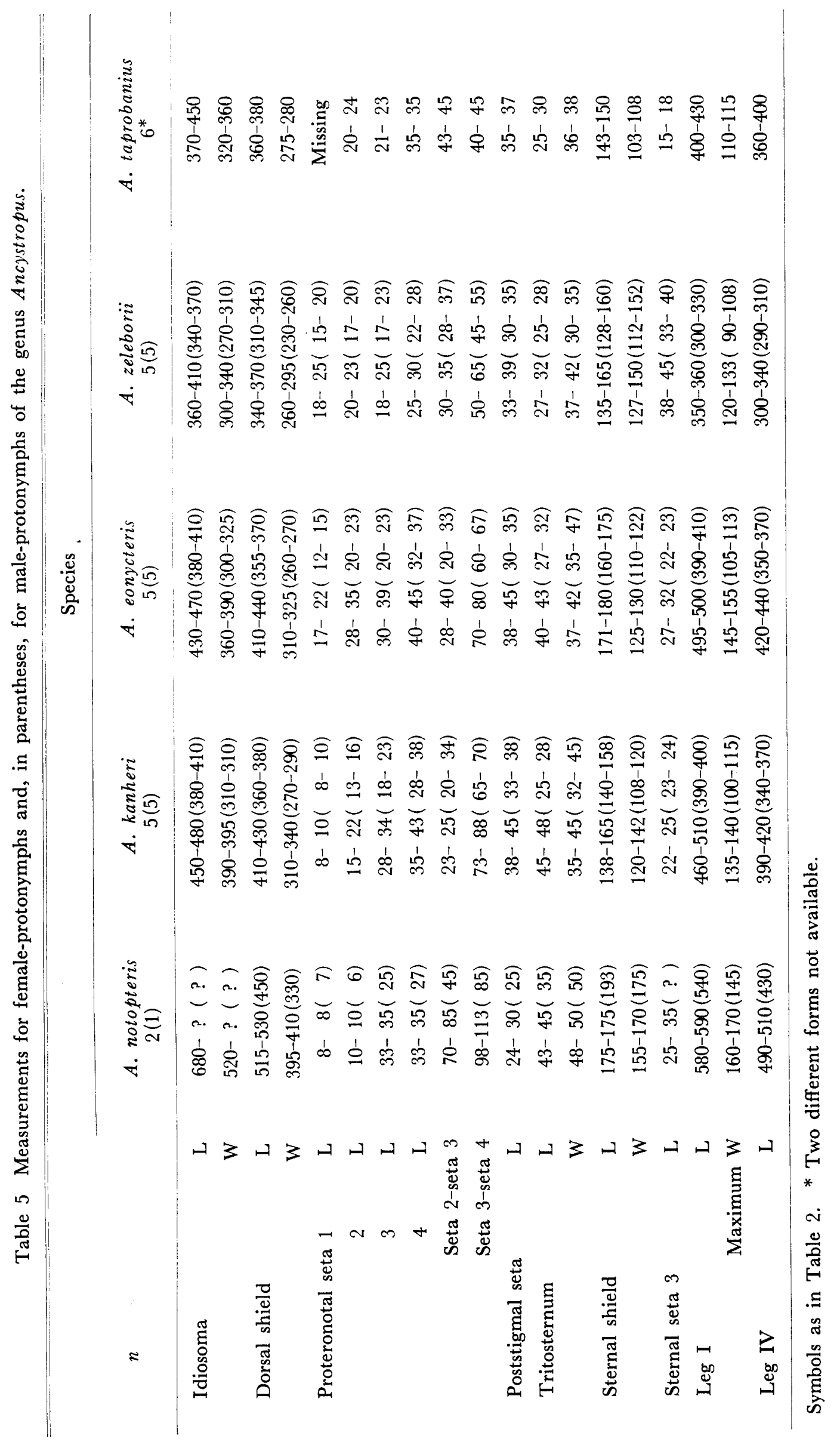


Female-protonymph. Dorsal shield entire, oval. Propodonotal and poststigmal setae well-developed compared with other species. Tritosternum roughly transverse trapezoidal, almost as long as wide, with lateral invaginations. Sternal shield trancate anteriorly and triangular posteriorly; postero-lateral margins weakly concave. Idiosomal setation as in all the preceding species.

Leg I thick and long; leg chaetotaxy as in A. notopteris and A. kanheri.

Measurements as in Table 5.

Male-protonymph. Leg I slender. Other structures, idiosomal and leg chaetotaxy as in female-protonymph.

Measurements as in Table 5.

Material examined. Ex Eonycteris spelaea: $2 \uparrow, 18 \hat{\delta}, 14 \mathrm{DN}, 13 \mathrm{PN}$, Khoa Wong Kot, Thamai, Jhanthaburi, Thailand, November 27, 1979; $1 \hat{\text {, }}$, Paktongchai, Nakhonrajasima, Thailand, November 22, 1979; 3PN, Tapkuang, Kangkoi, Saraburi, Thailand, November 18, 1979; 1PN, Amphoe Khok Pho, Pattani, Thailand, January 20, 1982; 19 from Thailand as recorded in
Uchikawa and Kobayashi (1978); $19,5 \hat{\delta}$, 1DN, 3PN, Poring, Sabah, Borneo, April, $1979 ; 1$ o , misidentified as $M$. mindanaoensis in Uchikawa and Kobayashi (1978). Ex Rousettus leschenaulti: $2 \uparrow, 2 \hat{\circ}, 2 \mathrm{PN}$, Mae Hongson, Thailand, July 31,$1978 ; 2 \hat{\jmath}, 2 \mathrm{DN}$, 1PN, Bam Klui, Banmi, Lopburi, Thailand,

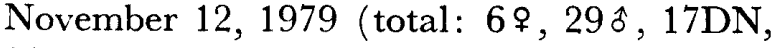
23PN).

All the above specimens are deposited in my collection.

\section{Ancystropus zeleborii Kolenati, 1856}

(Figs. 13, 14 and 19)

Male (Figs. 13, 14). Small mites less than 350 long. Proteronotal seta 1 short, yet relatively well-developed; setae 2 and 3 subequal to each other. Idiosomal setation as in preceding species. Tritosternum small, thin and stretched capsule-like, with weak projections at postero-lateral corners. Sternogenital shield triangular posteriorly, reaching to bases of genital setae, very clearly striated on a specimen from type host (Ethiopian region)

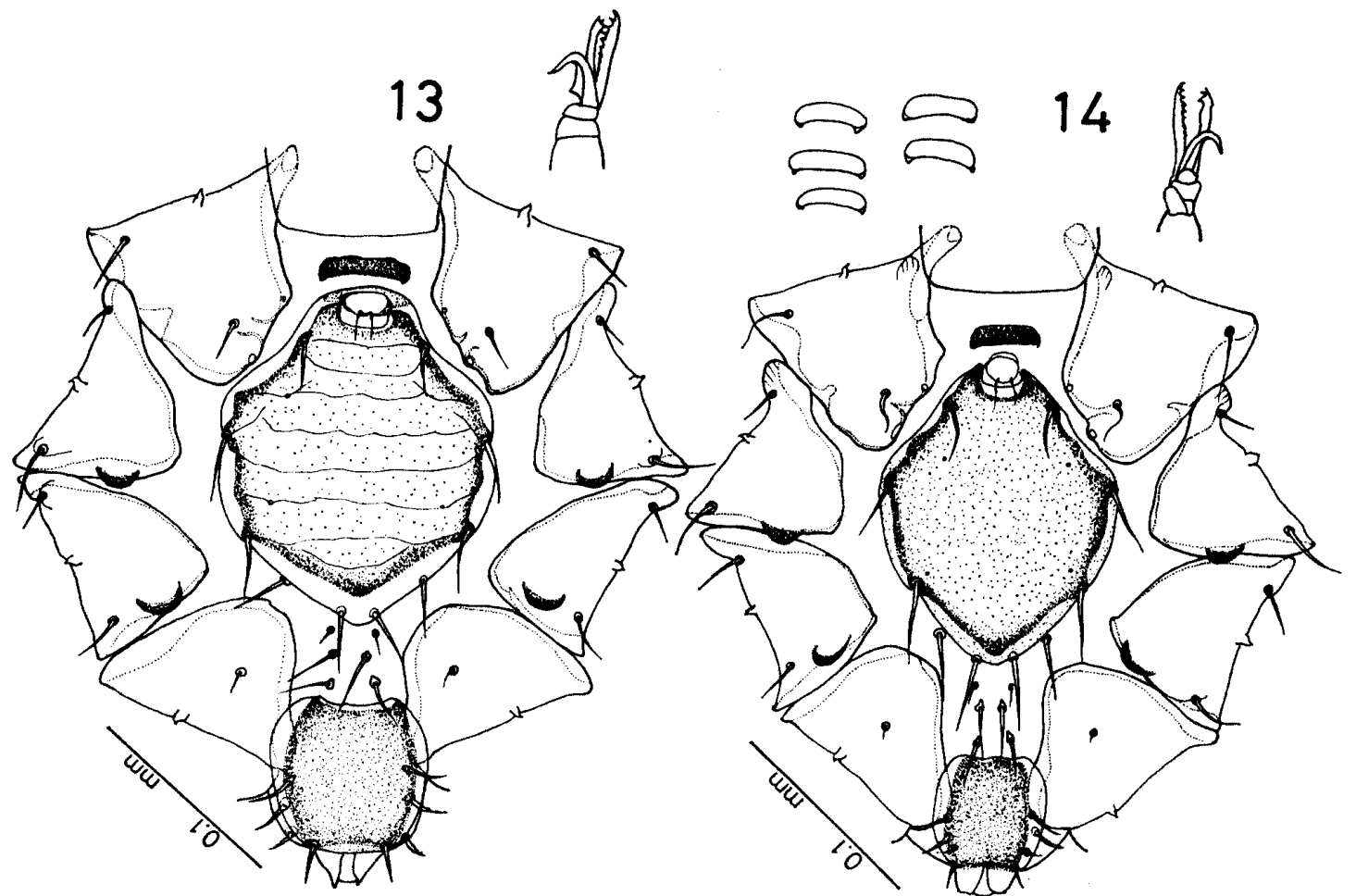

Figs. 13, 14 Male idiosomal venter, tritosternum and tip of chelicera of Ancystropus zeleborii Kolenati, 1856.

13: Ethiopian specimen from Rousettus aegyptiacus. 14: Oriental specimen from Rousettus leschenaulti. 
but not on all specimens from Oriental hosts (Figs. 13, 14), and bearing 3 pairs of strong setae. Metasternal and genital setae thick and almost as long as sternal seta 3. Adanal setae thinner than caudal setae.

Legs I and IV subequal in length to each other, but former thicker than latter; leg chaetotaxy as in A. eonycteris.

Spermadactyl strongly curved (Figs. 13, 14).

Measurements as in Table 2.

Female-deutonymph (Fig. 19). Small mites less than 400 long. Proteronotal setae subequal to one another. Idiosomal setation as in preceding species. Tritosternum square, wider than long (Fig. 19). Sternal shield similar to male sternogenital shield, broad, almost as wide as long, yet truncate anteriorly. Setae ventrally on idiosoma, inclusive of sternal setae, well-developed, rather thick and long. Of 3 pairs of caudal setae, posterior 2 pairs stout but shorter than metasternal and genital setae.

Leg I thick and cylindrical; 2 or, sometimes, 3 prominent protuberances discernible on anterior margin of coxa I (Fig. 19) unlike in other species; leg chaetotaxy as in adult.

Measurements as in Table 3.

Male-deutonymph. Smaller in all measurements than female-deutonymph. Leg I subequal in length to leg IV. A pair of slender adanal setae and 2 pairs of stout caudal setae present. Other structures inclusive of tritosternum, and setation on idiosoma and legs as in female-deutonymph.

Measurements as in Table 3.

Female-protonymph. Dorsal shield entire, oval. Idiosomal and leg chaetotaxy as in all the preceding species. Proteronotal setae 1-3 subequal to one another. Tritosternum and sternal shield almost the same in shape as those of deutonymph. Leg I distinctly thicker and slightly longer than leg IV; anterior margin of leg I armed with protuberances as in deutonymph.

Male-protonymph. Leg I slightly thicker than leg IV and both legs subequal to each other. Other structures and chaetotaxy essentially as in female-protonymph.

Female- and male-protonymphs not differing so markedly as in all the preceding species, so that some specimens remain unallocated to either sex.
Materials examined. Ex Rousettus aegyptiacus, the type host; $1 \hat{\delta}$, Temple Abusimbel, West Bank, Egypt, 1963 (RMNH 17668); 1 ㅇ, Travertijn Cave near Katana, Eastern Belg. Congo, 1956 (RMNH 16350). Ex Rousettus leschenaulti: 4ㅇ, $10 \hat{\delta}, 4 \mathrm{DN}, 2 \mathrm{PN}$, Tapkuang Kangkoi, Saraburi, Thailand, November 18, 1979; 2 $\delta$, 3DN, Bam Klui, Banmi, Lopburi, Thailand, November 12,

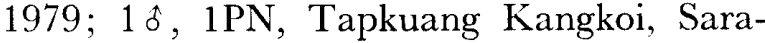
buri, Thailand, November 17, 1979; 1 \& , $4 \hat{f}$, 2DN, 1PN, Khoa Wong Kot, Thamai, Jhanthaburi, Thailand, November 27-28, 1979; 2 \&, $13 \hat{o}, 15 \mathrm{DN}, 13 \mathrm{PN}$, Khao Tagro, Muang, Lopburi, Thailand, December 2, 1979. Ex Rousettus amplexicaudatus: 1PN, Tapkuang, Kangkoi, Saraburi, Thailand, November 18, 1979. Ex Rousettus spelaea: 1DN, Khoa Wong Kot, Thamai, Jhanthaburi, Thailand, November 27, 1979. Ex Acedoron jubatus mindanaoensis*: 1PN, Tuganay, Mindanao, Philippines, November 20, 1946 (FMNH 74916-74918). Ex Dobsonia viridis champani*: 16우 4to, 3DN, 7PN, Bais, Pagyaburan, Negros, Philippines, May 13-14, 1949 (FMNH 66303-66310); 1 , Amoi, Santa, Caslina, Negros, Philippines, May 20, 1948 (FMNH 67859). Ex Cynopterus sphinx: $1 \%$, 4PN, Tapkuang Kangkoi, Saraburi, Thailand, November 18, 1979; 4 ㅇ, $3 \hat{\jmath}, 4 \mathrm{DN}$, 18PN; Sakaerat Station, Nakhonrajasima, Thailand, November 20-21, 1979; 2PN, Amphoe Khok Pho, Pattani, Thailand, January 20, 1982; 4PN, Doi Chang Kieng, Chiang Mai, Thailand, February 2, 1982. Ex Cynopterus brachyotis: 2PN, Gomantong Cave, Sabah, Borneo, April, 1979. Ex Cynopterus sp.: 1\%, 1ठ, 1DN, 7PN, Amphoe $\mathrm{Na}$ Ta Vee, Songkhla, Thailand, January 23-25, 1982. Ex Ptenochirus jagori: 4으, Sama Is., Philippines, April 9, 1957 (SMF 87714) ; 2 9, Katanglad, Mindanao, Philippines, May 12, 1965 (SMF 33336-33337). Ex Penthetor lucasi: 2 \&, 5DN, 8PN, Poring, Sabah, Borneo, April, 1979; 9ㅇ, Selangor, Malaysia, September 16, 1953 (FMNH 109124-109138) ; 1 ㅇ․ Fraser's Hill, Selangor, Malaysia, April 7-17, 1969 (AMNH 216743216745); $1 \delta, 3 \mathrm{PN}$, the same locality as above, October 8, 1969 (AMNH 233956); 3 \%, Sarawak, Malaysia, June, 1950 (FMNH 109120-109178); 10 , 1DN, 4PN, Malaya, 1950 (SMF 18352-18353, 18364-18371); 
49, Kajang, Malaysia, date uncertain (BMNH 60.838-848) ; 1 \%, Bukit Temedu, western part of Mts. Hose, Sarawak, Malaysia, date uncertain (BMNH 65.4155-4160). Ex Aethalops alecto*: 23\%, 2ิे, 1PN, Head Quarters, Kinabalu, Sabah, Borneo, August $12-18,1976$; 9 \% , $7 \hat{o}, 15 \mathrm{DN}, 23 \mathrm{PN}$, the same locality as above, April, 1979; $3 \hat{\delta}, 3 \mathrm{DN}$, 4PN, Poring, Sabah, Borneo, April, 1979; $1 \%$, Mt. Kinabalu, Sabah, Borneo, date uncertain (BMNH 65.330); 1 \%, Fraser's Hill, Selangor, Malaysia, January 3, 1973 (AMNH 216757-216759). Ex Haplonycteris fischeri* : $1 \hat{o}, 1 \mathrm{PN}$, Mt. Katanglad, Mindanao, Philippines, October-November, 1967 (SMF 28767-28839). Ex Alionycteris paucidentata*: 1\%, Mt. Katanglad, Mindanao, Philippines, date uncertain (BMNH 73 . 1790) (total: $100 \%, 55 \hat{\jmath}, 57 \mathrm{DN}, 107 \mathrm{PN}$ ).

The specimens taken from museum bats are deposited in the museums where they were taken, and others in my collection.

Remarks. Ancystropus zeleborii is the only species recorded from both the Oriental and Ethiopian regions. Rudnick (1960) redescribed both sexes and noted that the surface of the sternal shield was marked with distinct broken transverse lines in both sexes. This is also confirmed in the present study on a male and a female from Rousettus aegyptiacus, the type host. These striations are never observed on the adult and immature specimens from Oriental hosts, suggesting a distinct geographical variation. It is also probable that Ethiopian specimens are slightly larger than Oriental specimens.

A. zeleborii, the smallest species of $\mathrm{An}$ cystropus, seems to be most prevalent on Oriental hosts. It was found on 13 species of bats other than $R$. aegyptiacus. Of the 13 host bats, the 5 asterisked species are new hosts and the other 8 and some more species have already been recorded as hosts of $A$. zeleborii (Hiregaudar and Bal, 1956; Rudnick, 1960; Delfinado and Baker, 1963; Baker and Delfinado, 1964; Prasad ,1969, 1974; Domrow, 1972; Hill and McNeely, 1975; Cuy, 1979; Bhat et al., 1983). It is necessary to confirm the relationship of $A$. zeleborii with such new hosts as Acedoron jubatus, Haplonycteris fischeri and Alionycteris paucidentata that yielded only a few specimens of this mite.

\section{Ancystropus taprobanius (Turk, 1950)}

(Figs. 15 and 20)

Male (Fig. 15). Proteronotal seta 1 lacking; setae 2 subequal to or slightly longer than seta 3. A pair of postscutal and 2 pairs of caudal setae present as in all the preceding species. Tritosternum thick, rounded and sausage-like, with weak appendages on posterolateral corners (Fig. 15). Sternogenital shield caudally protuberant medially, barely reaching to basal level of genital setae, and bearing 3 pairs of weak sternal setae and 2 pairs of pores (Fig. 15). Metasternal, genital and 3 pairs of ventral setae also weak; adanal setae spiniform and short.

Legs relatively slender and long; leg chaetotaxy as in female as in Table 6.

Spermadactyl whip-like, very long.

Measurements as in Table 2.

Female-deutonymph (Fig. 20). Proteronotal seta 1 lacking; setae $2-4$ well-developed; setae 2 and 3 far apart from each other. Postscutal seta well-developed as in female, more than 20 long; 3 pairs of caudal setae strong with 1st pair more than 30 long, and 2nd and 3rd pairs spiniform. Four pairs of ventral setae present as in female and unlike other species; 4th pair stronger than preceding setae, situated closer to caudal setae than to 3 rd ventral seta. Tritosternum thick, and semicircular (Fig. 20). Sternal shield trancate anteriorly, tapering and ending bluntly or weakly protuberant posteriorly (Fig. 20), and bearing weak sternal setae. Metasternal, genital and ventral setae weak; adanal setae spinform and short.

Leg I not markedly different from other legs in appearance; leg chaetotaxy as in adult.

Measurements as in Table 3.

Male-deutonymph. Only 2 pairs of caudal setae homologous with 1 st and 4th pairs of female-deutonymph present as in other species. Leg I slightly thinner than in femaledeutonymph. Other structures and setations essentially as in female-deutonymph.

Measurements as in Table 3.

Protonymph. Sexes difficult to discriminate.

Dorsal shield entire. Proteronotal seta 1 lacking; setae 2 and 3 subequal in length; 


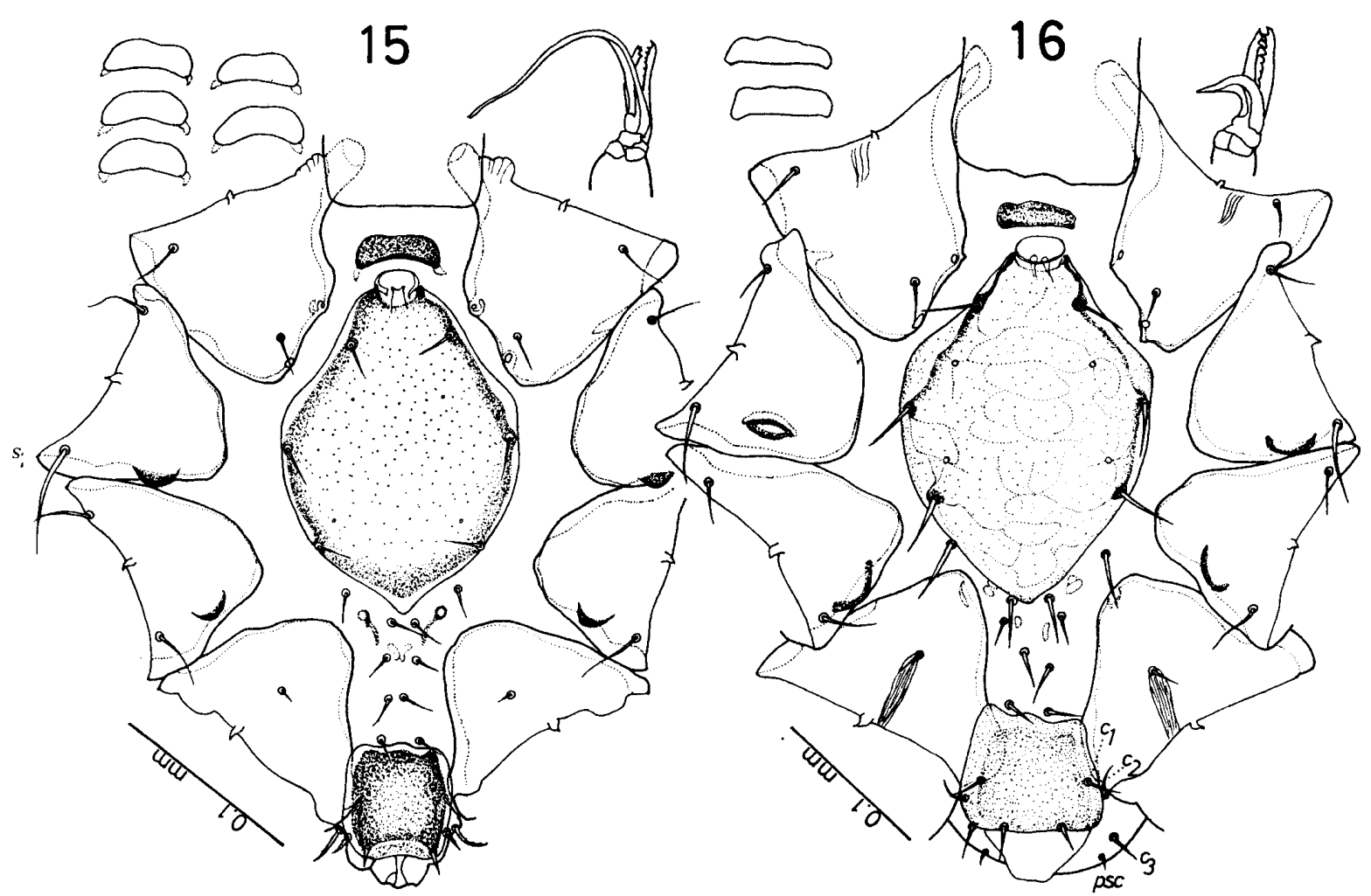

Figs. 15, 16 Male idiosomal venter, tritosternum and tip of chelicera.

15: Ancystropus taprobanius (Turk, 1950). 16: Ancystropus aethiopicus Hirst, 1923.

Table 6 Leg chaetotaxy of male (A. taprobanius).

\begin{tabular}{rrcccccc}
\hline & Coxa & Trochanter & Femur & Genu & Tibia & Tarsus \\
\hline \multirow{2}{*}{ Leg } & I & 2 & 5 & $2-4 / 3-2$ & $1-2 / 1,2 / 1-1$ & $1-2 / 1,2 / 1-1$ & 31 \\
II & 2 & 5 & $1-4 / 3-1$ & $1-2 / 1,2 / 1-1$ & $1-1 / 1,2 / 1-1$ & 16 \\
III & 2 & 5 & $1-3 / 2-0$ & $1-2 / 1,2 / 0-1$ & $1-1 / 1,2 / 0-1$ & 16 \\
IV & 1 & 4 & $1-3 / 1-0$ & $1-2 / 1,2 / 0-1$ & $1-1 / 1,2 / 0-1$ & 16 \\
\hline
\end{tabular}

Table 7 Leg chaetotaxy of protonymph (A. taprobanius).

\begin{tabular}{rrcccccc} 
& & Coxa & Trochanter & Femur & Genu & Tibia & Tarsus \\
\hline \multirow{2}{*}{ Leg } & I & 2 & 4 & $1-4 / 2-1$ & $1-2 / 1,2 / 1-1$ & $1-2 / 1,2 / 1-1$ & 25 \\
& II & 2 & 4 & $1-4 / 2-1$ & $1-2 / 0,2 / 0-1$ & $1-1 / 1,2 / 1-1$ & 15 \\
III & 2 & 4 & $1-3 / 1-0$ & $1-2 / 0,2 / 0-1$ & $1-1 / 1,2 / 0-1$ & 15 \\
IV & 1 & 4 & $1-3 / 0-0$ & $1-2 / 0,2 / 0-1$ & $1-1 / 1,2 / 0-1$ & 15
\end{tabular}

distances from seta 3 to setae 2 and 4 almost the same as each other. Tritosternum smaller but almost the same in shape as in deutonymph. Idiosomal setation as in other species. Other structures as in deutonymph.

Leg chaetotaxy as in Meristaspis protonymph as in Table 7.

Measurements as in Table 5.
Materials examined. Ex Rousettus leschenaulti: 2DN, Thum Khum, Khoawong, Banmi, Lopburi, Thailand, November 10, 1979; 3 9, 3 8 , Bam Klui, Banmi, Lopburi,

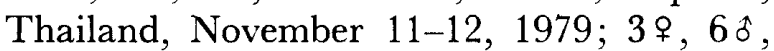
3DN, Tapkuang, Kangkoi, Saraburi, Thailand, November 18, 1979; $2 \hat{\delta}, 1 \mathrm{DN}, 3 \mathrm{PN}$, Khoa Wong Kot, Thamai, Jhanthaburi, 
Thailand, November 27-28, 1979; $3 \hat{\delta}, 4 \mathrm{PN}$, Khao Tagra, Muang, Lopburi, Thailand, December 2, 1979. Ex Eonycteris spelaea: $2 \hat{o}$, Khao Wong Kot, Thamai, Jhanthaburi, Thailand, November 28, 1979. Ex Dobsonia inermis: $1 \delta$, Solomon Is., 1964 (BBM-BSIP 23728). Host and data uncertain (BBM): $1 \hat{\delta}$ (total: $6 \%, 18 \hat{\delta}, 6 \mathrm{DN}, 7 \mathrm{PN}$ ).

Two males are in the BBM, and all the other specimens in my collection.

Remarks. Prasad (1969) presented accurate drawings for Ancystropus rudnicki Baker and Delfinado, 1964, a junior synonym of $A$. taprobanius, and noted that the spermadactyl was slender and curved toward its apex.

Domrow (1972) showed an aberrant proteronotal and leg chaetotaxy for A. taprobanius and thought that this mite was the only mobile member of the genus. The leg chaetotaxy of its protonymph is not the same as in other species of the genus but corresponds to that in Meristaspis, thus supporting Domrow (1972).

\section{Ancystropus aethiopicus Hirst, 1923} (Fig. 16)
500 long. Proteronotal seta 3 longer than seta 2. Minute postscutal seta and 3 pairs of slender caudal setae present as in female unlike other species. Tritosternum a distorted rectangle, with irregularly convex anterior margin. Sternogenital shield much longer than wide, faintly striated, tapering from a level in front of bases of sternal setae 2 and extending to basal level of genital seta, and bearing 3 pairs of strong sternal setae. Metasternal seta situated anteriorly closer to sternal seta 3 than to genital seta; both metasternal and genital setae strong.

Legs long; leg chaetotaxy as in $A$. notopteris and $A$. kanheri.

Measurements as in Table 2.

Immature stages not available.

Materials examined. Ex Epomops fra-

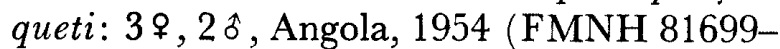

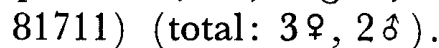

Two females and 1 male are deposited in the FMNH, and 1 female and 1 male in my collection.

Remarks. The male of A. aethiopicus is exceptional among its congeners in having a pair of minute postscutal setae and 3 pairs of caudal setae.

Male (Fig. 16). Large mite more than

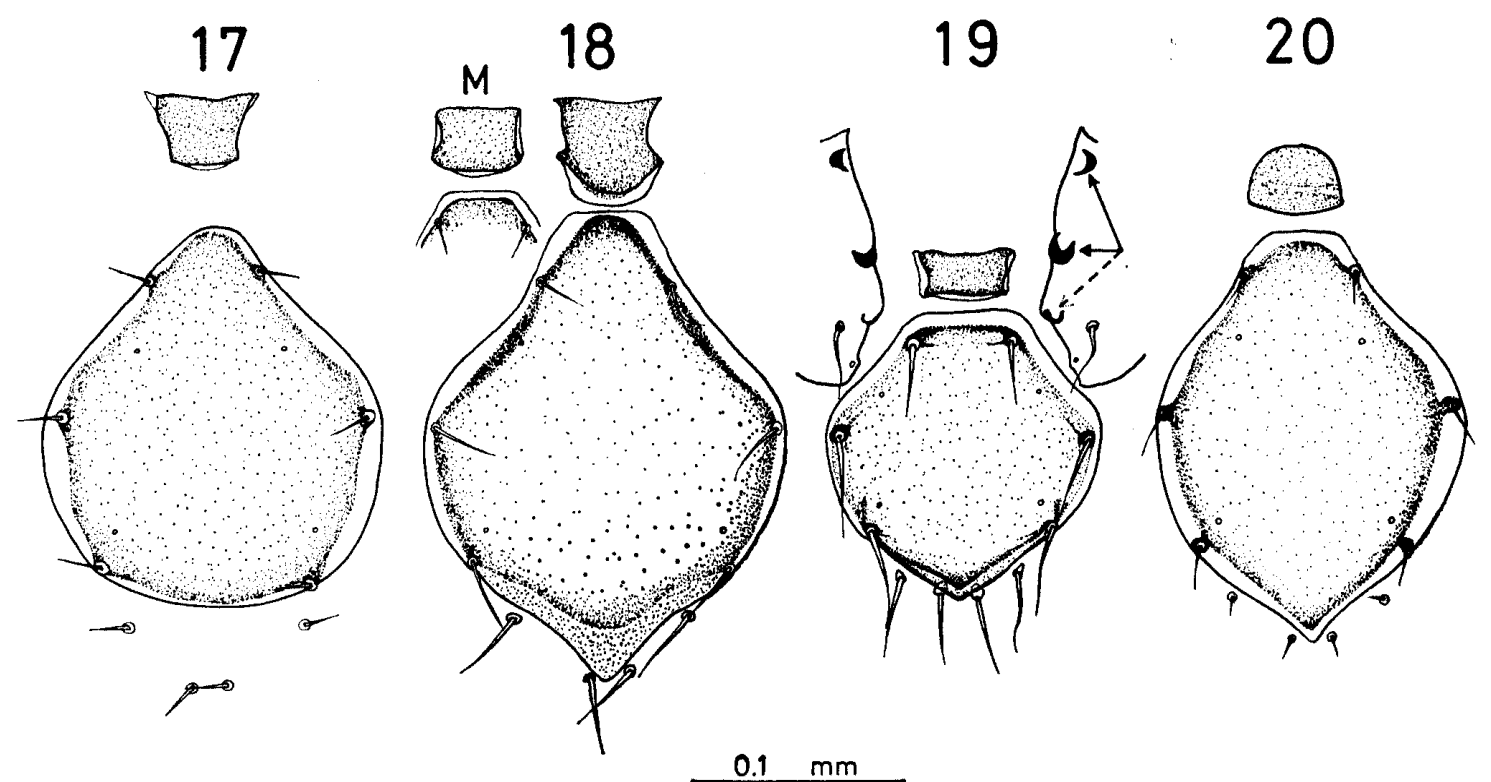

Figs. 17-20 Tritosternum, sternal shield, metasternal and genital setae of female-deutonymph. 17: Ancystropus kanheri Hiregaudar and Bal, 1955. 18: Ancystropus eonycteris Delfinado and Baker, 1963; M-anterior part of male-deutonymph. 19: Ancystropus zeleborii Kolenati, 1956, with coxae I showing characteristic protuberances (arrowed). 20: Ancystropus taprobanius (Turk, 1950). 


\section{Key to Males of Ancystropus}

(A. leleupi not available)

1. Proteronotal seta 1 missing. Tritosternum thick, rounded and sausage-like. Sternogenital shield protuberant caudally. Spermadactyl long and whiplike. Trochanter IV with 4 setae. Genua and tibiae IIIIV with 4 and 3 dorsal setae, respectively

A. taprobanius

Proteronotal seta 1 present. Tritosternum, sternogenital shield, spermadactyl not as above. Trochanter IV with 5 setae. Genua and tibiae III-IV with 2 and 1 dorsal setae, respectively .......... 2

2. Posterior margin of tritosternum weakly concave or almost straight. Sternogenital shield extending posteriorly beyond basal level of metasternal setae. Metasternal setae situated in front of genital setae. One or 2 ventral setae on femur IV. Spermadactyl curved strongly ...... 3 Posterior margin of tritosternum surrounding genital orifice. Sternogenital shield broadly rounded posteriorly, and barely or not reaching to basal level of metasternal setae. Metasternal and genital setae almost on the same level. Only 1 ventral seta on femur IV. Spermadactyl sinuate, not curved strongly ..... 5

3. Large mite more than 500 long. Postscutal seta minute and 3 pairs of caudal setae present. Tritosternum with straight posterior margin and lacking any protuberances on posterolateral corners. Sternogenital shield tapering from an anterior level to bases of sternal setae 2 . Only 1 ventral seta on femur IV. Spermadactyl ca. 50 long .... A. aethiopicus Smaller mite less than 400 long. Postscutal seta conspicuous and 2 pairs of caudal setae present. Tritosternum with protuberances on posterolateral corners. Sternogenital shield narrowed posteriorly from behind bases of sternal setae 3 . Two ventral setae on femur IV. Spermadactyl ca. 35 long ................ 4

4. Tritosternum stretched capsule-like. Sternogenital shield triangular behind sternal seta 3. Sternal, metasternal and genital setae thick and long ...... A. zeleborii Tritosternum with concave posterior mar- gin. Sternogenital shield rounded behind sternal seta 3. Sternal, metasternal and genital setae slender ...... A. eonycteris

5. Idiosoma less than 400 long. Tritosternum thick and trapezoidal, with concave posterior margin. Sternogenital shield pear-shaped. Sternal, metasternal and genital setae thin and short. Spermadactyl less than 50 long ........ kanheri Idiosoma more than 500 long. Tritosternum thin, broad and crescentic. Sternogenital shield flask-shaped. Sternal, metasternal and genital setae thick and long. Spermadactyl more than 80 long ...... A. notopteris sp. n.

\section{Key to Deutonymphs of Oriental Ancystropus}

1. Proteronotal seta 1 missing. Tritosternum thick, roughly semicircular. Female- and male-deutonymphs bearing 4 and 2 pairs of ventral setae, respectively. Metasternal and genital setae minute $\ldots \ldots \ldots \ldots$ A. taprobanius Proteronotal seta 1 present. Tritosternum not as above. Female- and male-deutonymphs bearing 3 and 2 pairs of ventral setae, respectively. Metasternal and genital setae conspicuous ............ 2

2. Sternal shield truncate anteriorly and narrowed posteriorly, reaching posteriorly to basal level of genital setae ........ 3 Sternal shield rounded anteriorly and broadly rounded posteriorly, not reaching to basal level of genital setae ....... 4

3. Small mite less than 400 and 350 long in female- and male-deutonymphs, respectively. Sternal shield almost as long as wide. Sternal setae thick and long. Two or 3 prominent protuberances on anterior margin of coxa I .......... Aeleborii Medium-sized mite more than 480 and 380 long in female- and male-deutonymphs, respectively. Sternal shield distinctly longer than wide. Sternal seta rather slender and short. No protuberances discernible on anterior margin of coxa I .............. A. eonycteris

4. Idiosoma less than 560 long in femaledeutonymph. Metasternal seta present. Tritosternum with invaginated lateral margins in female-deutonymph, square in 
male-deutonymph. Leg I $c a .550$ and $c a$. 400 long in female- and male-deutonymphs, respectively ....... A kanheri Idiosoma more than 700 long in female deutonymph. Metasternal seta missing in female-deutonymph. Tritosternum trapezoidal in female- and male-deutonymphs. Leg I 700 and 570-600 long in femaleand male-deutonymphs, respectively .... A. notopteris sp. n.

Since leg chaetotaxy is the same in the deutonymph as in the adult regradless of sex, differences by species in leg chaetotaxy are omitted in the above key.

\section{Key to Protonymphs of Oriental Ancystropus}

1. Proteronotal seta 1 missing, distance between setae 2 and 3 subequal to that between setae 3 and 4 . Genua and tibiae III-IV with 4 and 3 dorsal setae, respectively $\ldots \ldots \ldots \ldots \ldots$ A. taprobanius Proteronotal seta 1 present; distance between setae 2 and 3 distinctly shorter than that between setae 3 and 4 . Genua and tibiae III-IV with 2 and 1 dorsal setae, respectively ........... 2

2. Proteronotal seta 1 more than 15 long; setae 2 and 3 subequal ......... 3 Proteronotal seta 1 weak, less than 10 ; setae 2 much shorter than seta $3 \ldots .4$

3. Small mite less than 410 and 370 long, and leg I less than 360 and 330 long, in female- and male-protonymphs, respectively. Two or 3 prominent protuberances on anterior margin of coxa I ........ A. zeleborii Medium-sized mite more than 430 and 380 long, and leg I ca. 500 and ca. 400 long, in female- and male-protonymphs. No protuberance on anterior margin of coxa I .............. A. eonycteris

4. Medium-sized mite; dorsal shield 410-430 and 360-380 long, and leg I less than 510 and 400 long, in female- and maleprotonymphs, respectively. Proteronotal seta 2 more than 13 long .... A. kanheri Large mite; dorsal shield more than 500 and 450 long, and leg I nearly 600 and 540 long, in female- and male-protonymphs, respectively. Proteronotal seta 2 weak, less than 10 long ...........
A. notopteris sp. $\mathrm{n}$.

Since the shape of the tritosternum and sternal shields and the nature of the sternal setae are almost the same as in the maledeutonymph, specific notice of these characters is omitted in the above key.

\section{Discussion}

Studies of Ancystropus long concentrated on the conspicuous females, yet a precise evaluation of female key characters came as late as Domrow (1972). He reexamined females of all known species and showed the specific variations in proteronotal, hysterosomal, ventral and leg setations. Based on detailed observations, he included 6 species in the genus, relegating some earlier nominal species to synonymy. I follow his treatment of Ancystropus.

The female of the new species $A$. notopteris is close to $A$. kanheri and A. leleupi in sharing the same proteronotal and leg setations, but shows a new point in idiosomal setation, i.e. metasternal seta lacking. This is the one variation to be added to Domrow's observation on females of Ancystropus. Although the long postscutal seta is also a remarkable character of the new species, such a seta is found in the female of $A$. taprobanius.

The males have the same leg chaetotaxy as their respective partner females, but, unlike in females, the male proteronotal seta 1 is prominent in all species except $A$. taprobanius (that lacks this seta). The hysterosomal and ventral setations, inclusive of the metasternal seta, are the same in all males except $A$. leleupi (male unknown) and $A$. acthiopicus that bears inconspicuous postscutal setae and 3 pairs of caudal setae. Thus, adding to the proteronotal setae, there are 1 pair of poststigmal setae, 1 pair of conspicuous postscutal setae, 2 pairs of caudal setae, 3 pairs of ventral setae, 1 pair of genital setae and 1 pair of metasternal setae on the male idiosoma. There is no exception even in $A$. notopteris that lacks the metasternal seta in the female and in $A$. taprobanius that bears 4 pairs of ventral setae in the female instead of 3 pairs of other species. The key characters other than proteronotal and leg setations for differentiating males of Ancystropus are idiosomal size, shape of 
tritosternum and sternogenital shield, nature of sternal setae, nature and position of metasternal and genital setae, and shape and size of spermadactyl.

There is distinct sexual dimorphism in the deutonymphal stage of the Oriental species. The female- and male-deutonymphs are associated morphologically with their respective adults as pointed out by Rudnick (1960), but the proteronotal seta 1 and postscutal seta tend to be more conspicuous in femaledeutonymphs than in adult females. $A$. eonycteris shows the most remarkable sexual difference among the 5 Oriental species in the size of the idiosoma and leg I and in the shape of tritosternum in this stage. Other specific characters for the deutonymph are those described above for the males. It is highly probable that the Ethiopian species, $A$. aethiopicus and $A$. leleupi, also have specific characters to differentiate them from one another and from the 5 Oriental species in the deutonymphal stage.

In the protonymphal stage, sexual dimorphism is apparent in the size of idiosoma and leg $\mathrm{I}$ in $A$. notopteris, A. kanheri and $A$. eonycteris, not so apparent in $A$. zeleborii and not discernible in A. taprobanius. Proteronotal setae 1-4, 1 pair of poststigmal setae, 1 pair of postscutal setae, 2 pairs of caudal setae, 1 pair of genital setae and 2 pairs of ventral setae are persent in all species, and proteronotal seta 1 is missing only in A. taprobanius. A common leg setation is shared by $A$. notopteris, $A$. kanheri, $A$. eonycteris and $A$. zeleborii, while the leg setation of A. taprobanius is the same as that in Meristaspis spp. Some other specific characters found in the more advanced stages are also observed in each species in the protonymphal stage.

In the female, serial changes were thoroughly evaluated by Domrow (1972). More advanced specialization of some characters of leg I and significant deficiency or reduction in proteronotal, ventral and leg setae were noted carefully through comparison of homologous characters of all the known species. On the basis of finding specimens of Ancystropus attached somewhat like ticks, their legs I and mouthparts being tightly embedded in the skin of the arm-pits of Malayan bats, and of $A$. kanheri with legs I often snapped-off, Domrow (1972) thought there was a tendency in Ancystropus to change from tactile to prehensile life on the host. Thus the above serial changes in some homologous characters among Ancystropus females should not to be treated independently, but as facets of one and the same tendency as suggested by Domrow (1972).

The female-deutonymphs resemble morphologically their respective females, yet specialization of proteronotal setae (especially 1 and 2) and legs $I$ is far inconspicuous in the former, suggesting that there is a difference between the two stages in attaching habit and that the deutonymphal stage is preparatory for a remarkable sexual dimorphism in the adult stage. Related to this, prominent dimorphism in the protonymphal stage as in $A$. kanheri, A. notopteris and A. eonycteris might be indicative of conspicuous difference between both sexes in the advanced stages. The male, male-deutonymph and protonymph seem not to be specialized enough to have prehensile function, compared with congeneric females and corresponding stage of other spinturnicid genera. However, it is reasonable to estimate that the male, having direct contact with its partner female during mating, should have acquired some apomorphic characters in accordance with specialization of the female. The 3 types of spermadactyls found in the 6 species of the genus are thought to be one of such changes in response to specialization of proteronotal setae, leg I and/or physogastry of partner females, although mating behavior cannot be visualized clearly. The male of $A$. taprobanius (a species with many curious characters in the female and is proposed as the only mobile member of the genus by Domrow, 1972) has extraordinarily long and whip-like spermadactyls, while those of $A$. eonycteris, A. zeleborii and A. aethiopicus are provided with hooked or curved spermadactyls. The 3rd type of spermadactyls is found in $A$. kanheri and $A$. notopteris where they are not hooked but weakly sinuate and rather long. Since all female characters of $A$. kanheri and $A$. notopteris are similar to those of $A$. leleupi, the unknown male of $A$. leleupi is presumed to have the 3rd type of spermadactyls. Compared with cases of all spinturnicid mites, the sinuate and extraordinarily long 
spermadactyls are thought to be an apomorphic state. The metasternal and genital setae arranged on the common level concomitant with the posteriorly shortened and rounded sternogenital shield are also thought to be derived characters found in only a few species. No other male character obviously associated with evolution of Ancystropus has yet been noticed. Thus the apomorphic characters are:

1. Pulvillus I absent (generic character in female only)

2. Genua and tibiae III-IV with 2 and 1 dorsal seta, respectively (all species other than $A$. taprobanius in all stages)

3. Proteronotal seta 2 reduced ( $A$. kanheri, $A$. notopteris and $A$. leleupi, in female and, to a lesser extent, all other stages of the former two)

4. Metasternal seta absent (A. notopteris in female and female-deutonymph)

5. Three pairs of ventral setae (all species except $A$. taprobanius in female and female-deutonymph)

6. Basal anteroventral seta knob-like (all species except $A$. taprobanius and $A$. aethiopicus in female)

7. Only a single ventral seta on femur IV (A. aethiopicus, A. leleupi, A. kanheri and $A$. notopteris in adult and deutonymphal stages)

8. Leg I armed with (in female only): strong lateral and posteroventral hooks on distal 5 segments and a spur anteroventrally on genu and tibia ( $A$. zeleborii and $A$. aethiopicus); small lateral hooks on distal 5 segments and a spur anteroventrally on genu and tibia $(A$. eonycteris); only a spur anteroventrally on genu and tibia (A. leleupi and A. kanheri); a finely striated patch anteroventrally on femur, genu and tibia ( $A$. notopteris)

9. Spermadactyl extraordinarily long and whip-like, or sinuate ( $A$. taprobanius and $A$. kanheri, $A$. notopteris and probably $A$. leleupi, respectively)

10. Sternogenital shield posteriorly shortened and rounded, and metasternal and genital setae arranged on a common level ( $A$. kanheri and $A$. notopteris)

11. Sexual dimorphism obvious in protonymphal stage (A. eonycteris, $A$. kanheri and $A$. notopteris)

Reduction of a ventral or anterolateral seta occurs concomitantly on trochanter and femur IV and on genu and tibia I in $A$. taprobanius. So setal reduction on femur IV of this species is not dealt with in the same way as in the other species in the above article 7 .

Concerning the lateral and ventral armature of female leg I, modified and conspicuous lateral setae as observed in A. taprobanius (as well as in Meristaspis spp.) might have been changed to such conspicuous lateral and ventral hooks and spurs as in $A$. zeleborii, which might gradually have regressed to the degree noticed in $A$. notopteris that bears only a finely striated patch ventrally on anterodistal corner of femur, genu and tibia I. Accordingly, in the article 8, the latter is thought to be in the more advanced state. The bulky hook found posterodistally on tarsus $\mathrm{I}$ of $A$. kanheri is thought to be an exceptional and purely specific character incompatible with homologous structure of other spinturnicid species.

It is important to know where such apomorphic characters have come out in accordance mainly with the specialization of females. To find a clue to this problem, ecology of all members of Ancystropus, inclusive of behavioral habits, distributional patterns, host ranges and restricted locations on hosts, should be studied thoroughly. Only fragmentary knowledge on host relations is available at present, yet, using it, an attempt to interpret the above problem is made below.

$A$. aethiopicus, $A$. leleupi, $A$. eonycteris, $A$. kanheri and the new species $A$. notopteris may be restricted to a few hosts, but records are few. Contrary to this, A. zeleborii and, to a lesser extent, $A$. taprobanius have repeatedly been recorded from various hosts, suggesting their host ranges are wide. Accordingly, no established host relationship of Ancystropus is deducible from host record analyses. On the other hand, some bats are remarkable as hosts of 2 or more species of Ancystropus. Rousettus leschenaulti (Hiregaudar and Bal, 1956; Hill and McNeely, 1975; Bhat et al., 1983; the present study), Rousettus amplexicaudatus (Cuy, 1979), Rousettus stresemanni (Domrow, 1972) and Cynopterus brachyotis (Hill and McNeely, 
1975) have been recorded as hosts of the 3 Ancystropus species, A. taprobanius, A. zeleborii or A. eonycteris (only on C. brachyotis) and $A$. kanheri. Eonycteris spelaea was the host of A. taprobanius, A. zeleborii, A. eonycteris and $A$. kanheri in the present study and of the first 3 species in Hill and McNeely (1975), though the relations of some mites with this bat must be confirmed. Rousettus aegyptiacus is the type host of A. zeleborii and A. leleupi (Benoit, 1959; Rudnick, 1960). Although some false records might be included, there are many other examples of synhospitality by 2 Ancystropus species. Further, all the above host bats are parasitized by Meristaspis lateralis together with their respective Ancystropus mites.

A tendency of heavy synhospitality of $A n$ cystropus and simultaneous occurrence of its relatives on some Rousettus and others might have been realized through either secondary establishment or successive speciations of mites on a given host. Combinations of the synhospitalic mites recorded above indicate that mites with different spermadactyl types such as $A$. taprobanius with extraordinarily long and whip-like spermadactyls, A. zeleborii and $A$. eonycteris with hooked ones and $A$. kanheri or $A$. leleupi with sinuate ones occur far more often than combinations of mites with the same spermadactyl type, suggesting behavioral differences among synhospitalic males. Provided the change in the formation of spermadactyls is related to the specialization of partner female as thought before, the females of synhospitalic mites are thought to have acquired sympatric speciation through habitat or behavior segregation on a given host. On the other hand, data supporting transfer and secondary establishment of Ancystropus mites on any host have so far not been clearly shown. Thus, successive speciations independent of host speciations should not be neglected in thinking of evolution of mites, incorporating this into a discussion of host phylogeny, within the genus Ancystropus. This is a warning to some parasitologists who are ready to use endo- and/or ecto-parasites merely as labels in evolutionary analyses of their hosts, without investigating biological properties of parasites.

\section{Acknowledgements}

I sincerely thank Dr. R. Domrow, Queensland Museum, Brisbane, for reading a typescript of the present paper and Ms. M. Yamamoto for typing it.

Partial financial support was provided by Overseas Scientific Research Grant Nos. 57041019 and 58043013 from the Ministry of Education, Science and Culture of Japan (Contribution No. Ac18).

\section{RefERENGES}

Baker, E. W. and M. D. Delfinado (1964): Spinturnicidae of South East Asia and the Pacific region. Pac. Insects, 6: 571-591.

Benoit, P. L. G. (1959): Un nouveau spinturnicide sur chauves-souris frugivores du Congo belge (Acarina-Mesostigmata). Rev. Zool. Bot. Afr., 59: 106-108.

Bhat, H. R., S. M. Kulkarni and A. G. Mishra (1983): Records of Mesostigmata, Ereynetidae and Pterygosomidae (Acarina) in Western Himalayas, Sikkim and Hill Districts of West Bengal. J. Bombay Nat. Hist. Soc., 80: 91-110.

Cuy, L. S. (1979): Synopsis of Philippine Spinturnicidae (Acarina: Mesostigmata). Kalikasan, Philipp. J. Biol., 8: 162-172.

Delfinado, M. D. and E. W. Baker (1963): Mites of the family Spinturnicidae from the Philippines (Acarina). Pac. Insects, 5: 905-920.

Domrow, R. (1972): Acari Spinturnicidae from Australia and New Guinea. Acarologia, 13 : 552-584.

Dusbábek, F. and W. Bergmans (1980): Spinturnicid mites from some Nigerian bats (Acarina, Spinturnicidae). Bull. Zool. Mus. Univ. Amsterdam, 7: 65-72.

Evans, G. O. (1968): The external morphology of the post-embryonic developmental stages of Spinturnix myoti Kol. (Acari: Mesostigmata). Acarologia, 10: 589-608.

Hill, J. E. and J. A. McNeely (1975): The Bats and Bat's Parasites of Thailand, 1-87.

Hiregaudar, L. S. and D. V. Bal (1956): Some ectoparasites of bats from India. Agra Univ. J. Res. (Sci.), 5: 1-134.

Prasad, V. (1969): Bat mites (Acarina: Spinturnicidae) mainly from South-East Asia and the Pacific region. Acarologia, 11: 657-677.

Prasad, V. (1974): Parasitic mesostigmatic mites from Nepal (Acarina: Mesostigmata). Orient. Insects, 8: 63-70.

Rudnick, A. (1960): A revision of the mites of the family Spinturnicidae (Acarina). Univ. Calif. Pub. Entomol., 17: 157-283.

Turk, F. A. (1950): Studies of Acari. IV. Parasitic mites from mammalian hosts obtained in 
Ceylon. Parasitology, 40: 36-76.

Uchikawa, K. and T. Kobayashi (1978): A contribution to the ectoparasite fauna of bats in Thailand II. Blood-sucking Acari (Argasidae, Spinturnicidae and Macronyssidae). Contr. Biol. Lab. Kyoto Univ., 25: 249-254.

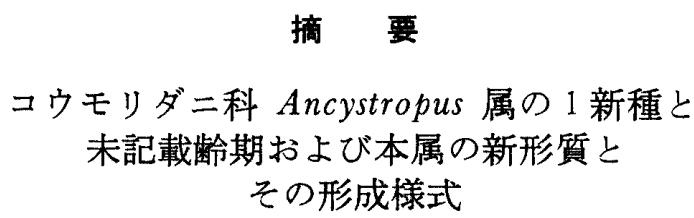

Ancystropus 属の 1 新種 A. notopteris を全発育齢 期（雌, 雄, 第 2 若虫, 第 1 若虫）に基づいて記載し た. 本属の全既知種のうち $A$. leleupi を除く 5 種に ついて, 雄の再記載 (1 種) または記載を行った. 東 洋区に分布する A. kanheri, A. eonycteris, A. zeleborii および A. taprobanius の若龄期を記載した. Ancystropus 属の新形質を評価し, 新形質が本属ダ二 類の同所性種形成に伴って出現したものと考えた. 